counting and instrumental choice behaviour, he proposes - among other things a new approach to simple associative learning based on computation of rate as well as a scheme for representing vector quantities in the nervous system. People working in some of the areas which he reinterprets, like pavlovian conditioning, may be irritated by his selective treatment of the literature (that the book is as long as it is reflects the extensiveness with which a few telling examples are discussed rather than any attempt at a comprehensive review) or baffled by the unfamiliar mathematics. Nevertheless, the material in this book has to be reckoned with by anyone involved in the behavioural or neural analysis of learning. It is a unique and exciting attempt at a unified account of how animals store and use information about their worlds.

Sara J. Shettleworth is in the Department of Psychology, University of Toronto, Toronto, Ontario M5S 1A1, Canada.

\section{III-conceived project}

\section{Richard Ruquist}

Nuclear Dynamite: The Peaceful Nuclear Explosions Fiasco. By Trevor Findlay. Brassey's Australia: 1990. Pp.339. $£ 19.50, \$ 35$.

IN the 1960s the US Atomic Energy Commission (AEC) was seemingly more concerned with the survival and maturation of project Plowshare, a programme to develop peaceful nuclear explosions (PNEs), than it was with the proliferation of nuclear weapons. Non-proliferation was the concern of the US Arms Control Disarmament Control Agency (ACDA). In ACDA's view ". . . the technology of making nuclear explosive devices for peaceful purposes is indistinguishable from the technology for making nuclear weapons. .." The consequential schizophrenic US policy, fostered by indifferent presidents and a split bureaucracy that pit the AEC against the ACDA and the Bureau of the Budget, interfered with the US acceptance of important arms control treaties, namely the Limited Test-Ban Treaty and the Non-Proliferation Treaty, and it helped to subvert a comprehensive test-ban, according to Trevor Findlay in Nuclear Dynamite.

Plowshare, like other US nuclear programmes, was born and nurtured by a scientific, bureaucratic and political alliance. The principal personalities of this alliance were: Edward Teller of the University of California Lawrence Livermore Laboratory, famed inventor of the fusion bomb, who helped initiate the Strategic
Defense Initiative (SDI) programme; Glenn Seaborg, the Director of the AEC from 1961 to 1971 , who shared the Nobel Prize for the discovery of plutonium; and the Californian congressional members of the Joint Commission of Atomic Energy, Republican Craig Hosmer and Democrat Chet Holifield, its long-standing chairman. Findlay credits Teller with the longevity of this "ill-conceived project". No doubt a relatively small budget that peaked at $\$ 18$ million in 1968 also helped, not counting untold amounts borrowed from the weapons programme. The alliance was backed by a strong constituency in science and industry. In the end, both became disenchanted. But not Teller. He seems to hold true to a desire expressed to Enrico Fermi in 1945 - to develop the fusion bomb to extend our power over natural phenomena.

The history of Plowshare is complete. Trevor Findlay presents it from beginning to end in 16 chapters, five appendices and a wealth of footnotes. Included with this history are discussions of similar programmes in Australia, Argentina, Brazil, India and the Soviet Union, all stimulated by over zealous promotion of Plowshare. One chapter is devoted to the Soviet programme, a programme that dwarfed that of the United States in all aspects, yet was only initiated in 1964 in response to Plowshare, following a long period of Soviet anti-PNE sentiment. Besides numerous nuclear test-site experiments, the Soviet programme has consisted of at least 110 field-tests, whereas the US programme had only 35 tests in total, and three illfated field-tests.

This is not a dispassionate history, for Findlay speaks from the perspective of an arms controller. A former member of the Australian disarmament delegation from 1979 to 1984 and currently at the Australian National University Peace Research Centre, he makes the case against nuclear dynamite in fascinating detail. With a light and sometimes cynical touch, he usually lets the history of Plowshare speak for itself. He discusses various applications of PNEs and all of the major US experiments in detail. But Nuclear Dynamite is mainly about the politics of Plowshare: how it was initially used to argue, to no avail, against nuclear test moratoriums and treaties; how President Johnson took political advantage from the programme; and how the Limited Test-Ban Treaty continually hemmed in the programme.

The possibility of building a new isthmus sea-level canal by nuclear excavation was used by President Johnson to keep Panama at bay while renegotiating a new Panama Canal Treaty. This was the life-blood of Plowshare in the late 1960s. As part of this scene, Findlay presents an intriguing account of a Teller-initiated Australian harbour-creation project, a trial run for the Panama Canal project, that failed to materialize for a myriad of technical and economic reasons.

The thrust of the Plowshare programme appeared to reach fruition in 1970 , when a provision that institutionalized PNEs was incorporated in the Non-Proliferation Treaty. But the programme then immediately encountered a series of setbacks. In the summer of 1970 the first thorough study of nuclear excavation was released, the [Panama] Canal Commission Report. It demolished the technical and economic justification for surface applications. Actually the programme had already gone underground following the 1968 35KT Schooner cratering experiment in which significant levels of radioactivity were released into the atmosphere, thereby violating the Limited Test-Ban Treaty. The setbacks continued as a series of underground tests were cancelled by feasibility studies or by opposition from citizens. Three field experiments were performed to stimulate the enhanced release of natural gas, but these provoked controversy, proved ineffective, and the gas industry lost interest. A project to produce underground storage facilities was killed by citizen unrest.

Findlay admits to one possibly useful application of PNEs, that of building deep underground storage cavities for radioactive waste. Ironically, this concept was killed by the AEC itself because it was contrary to established policy. All testing ended in 1973. Congress abolished the $\mathrm{AEC}$ in 1974 and forbade the funding of any field testing of nuclear explosives for the recovery of gas or oil.

The ground-swell of citizen concern for the environment was beginning to take effect. Finally, the 1974 test of a nuclear device in India, for the expressed purposes of peaceful nuclear explosions, fixed world opinion against PNEs. Findlay credits the supersedence of the arms controllers to grass-roots popular support. A weakness of this book is that it pays very little attention to the efforts of various arms control and environmental organizations, both public and private, to develop that support. Findlay does make a strong case for a comprehensive test-ban that abolishes PNEs, rather than a separate PNE treaty that might make them legitimate. He believes that the time for a comprehensive treaty has arrived.

After all, the Soviets in 1977 were prepared to accept a suspension of all underground tests including a moratorium on PNEs. Since then the Soviet excavation programme has been shelved by the direct intervention of Gorbachev. Unfortunately, the Reagan administration decided not to resume negotiations in 1982 in response to the needs of the nuclear weapons industry.

Richard Ruquist, 27 Edgewood Road, Lexington, Massachusetts 02173, USA. 